\title{
New Toolkits for Regional Sustainable Development
}

\author{
Zentrale Elemente von Nachhaltigkeit sind ein langfristiger Zeithorizont und \\ Politikintegration. Um dies auf regionaler Ebene zu erreichen, sind neve Kom- \\ munikationsformen notwendig. Als Katalysator können eine Reihe never, com- \\ putergestützter Informations- und Kommunikationsinstrumente dienen. Insbe- \\ sondere ihre Integration trägt dazu bei, kritische Masse-Effekte, zersplitterte \\ Verantwortlichkeiten und Kurzfristdenken zu überwinden.
}

$\mathrm{T}$ Von Joe Ravetz but they all focus on long-term time horizons and integration between different policy sectors. However, at present, most thinking and communication is short term and dis-integrated between sectors. This suggests that we need new kinds of communication to help the move towards sustainable development (SD).

Communication for SD is a complex mix - data and information systems for technical signals, market and policy pressures for economic and political signals, and discourse or persuasion for cultural and psychological signals. New methods and tools - what we call here toolkits - can be catalysts for improved communications. Each toolkit can be seen as a system for processing information, with applications such as planning, investment, management, appraisal, modelling and monitoring. With the aid of the revolution in information and communications technology, each of these applications shows a trend of convergence towards the others - drawing from a common information base, and drawing on the techniques of the others. This suggests that we could help to move towards SD at the regional level by accelerating this convergence with new and more powerful toolkits.

In this brief paper we begin with some key issues for regional SD, and opportunities for practical action. Then we look at the many barriers, the toolkits which can help to overcome them, and we point to some current examples.

\section{Why not Regional?}

First I would like to ask - why are regions not cornerstones of sustainability (1):

- Lack of definition: many regions overlap, and the boundaries of economic, political, social and environmental systems are often all different.

- Political and economic dependency: nations generally have the ultimate legal and financial powers: some regions have more powers, some less, and these have to be negotiated.

- Urbanization and globalization: regional economies generally operate and compete on a global scale, taking in resources and producing goods for the nation and the world.

However, at the regional level there is often a strong correspondence and „fit" between physical functions, social identity, economic units and political territories. The environmental features of regional units include water catchments, air dispersion bowls, soil types and agricultural markets. The economic features include urban hinterlands, travel patterns, housing markets, trade flows, and industrial profiles. Most regions have a strong sense of identity, linked with language and customs, and with kinship or migration patterns. The new ,policyscape" of agencies, programmes and objectives, are each intended to be joined at the regional level, and may have better chances for success than at local or national levels. In general the regional level, where policy is often in a greater state of flux, and where the „connexity" of sectors and actors can be increased (2), offers the chance of new linkages:

- horizontally, between different sectors or policy silos,

- vertically, between top-down providers and bottom up consumers,

- laterally, between upstream causes and downstream effects, and

- culturally, between different worldviews, ethics and cultures (Fig 1)

So much for the principles. The reality is that regional policy choices face similar challenges as local and national, with conflicts between growth, decline, stability and change - whether to create playgrounds for the globalized rich, or republics for the native poor? The current regional SD strategies, certainly in the UK, show a difficult balance between low-risk adjustments to the status quo, and high-risk aspirations for a better world. The practical question is in the centre of this balance - what are the opportunities for SD, and what toolkits in information/ communications systems might help to enable them? This would take a book to explore, of which City-Region 2020 is one attempt (3), so here are just a few examples.

\section{Regional Opportunities}

For the built environment sectors, many regions are attempting to fit the SD agenda for compact cities and neighbourhoods, with business parks and airport runways. Such conflicts can be mediated with a regional bousing strategy and regional property strategy - more than plans, these are operational frameworks for planners to coordinate with financiers, housebuilders, landlords, developers, utilities, retail, health and education services. Meanwhile the largest single environmental impact is caused by the stock of housing and commercial buildings. A regional buildings strategy would provide for rising standards while reducing $\mathrm{CO} 2$ emissions and other emissions by 40 per cent or more.

A regional energy-climate strategy: this aims to transform and de-carbonize the regional energy metabolism, through a partnership coordination between demand and supply sides:

- Regional climate response and mitigation programme to monitor risks and opportunities,

- energy services firms and regional energy agency to accelerate efficiency in all sectors, with a combined heat and power programme for urban and industrial areas,

- regional renewables programme, linking landowners and utilities to public purchasing policies. Each of the above, and more, depends on a regional SD economic development strategy. This is a case for the regional investment funds now setting up in the UK and other countries, to be targeted on green finance at every level of the regional system. Such funds would be run by a partnership of commercial banks, regional development agencies and government offices. Their main objective would be in bridging market barriers to increase the viability of investment in SD ventures and technologies.

This regional SD economic strategy would take many different forms such as: 


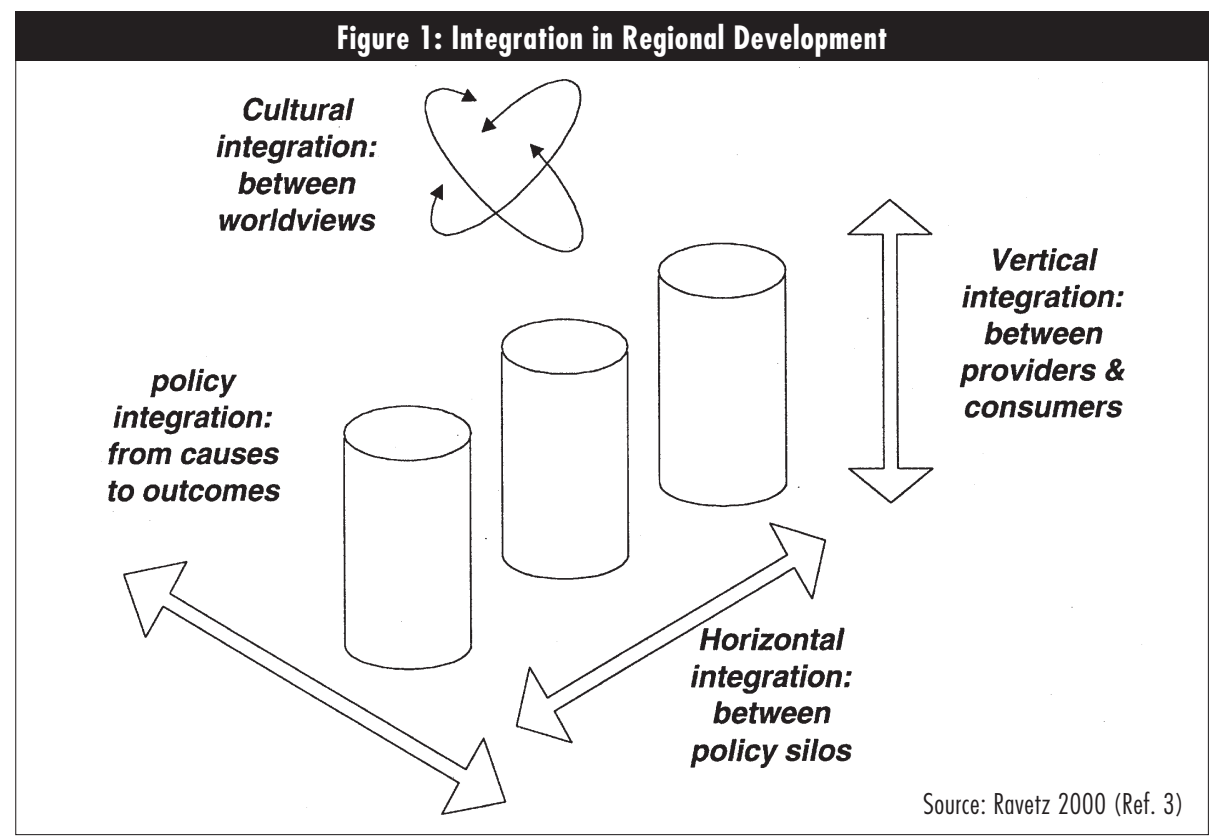

Clean technology growth pole with technology transfer network, linking research, higher education and industrial bodies,

- market development programme, linking green investment and public purchasing policies to venture capital and supply chains,

- preferential finance for environmentally accredited businesses and projects, as piloted by the Cooperative bank,

- infrastructure development: long term equity or financial underwriting to environmentally-led schemes such as combined heat and power,

- partnership agencies: preferential capital, equity investment and underwriting to the regional energy agency, transport agency and similar consortium bodies,

- employment development programme: tackling unemployment, community capacity building and local business development, with energy efficiency and similar programmes.

\section{Barriers ...}

Each of these examples is a powerful illustration of what is possible, and what is urgently needed if the macro-scale SD agenda is to be realized. But at present the reality is that each of these is held up by inertia and progress is slow. From the economic perspective, there are strong market barriers which hinder many of the types of investment and trading which is essential for regional SD. Such market barriers include, with typical examples in brackets:

- Critical mass - where new technology cannot compete because large scale demand or supply do not yet exist (example: renewable energy),

\section{politische ökologie ${ }^{63-64}$}

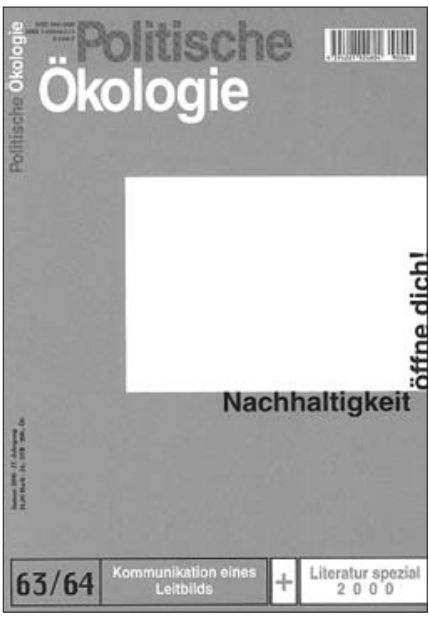

\section{Nachhaltigkeit öffne Dich!} fits go to different groups (ex : public transport) - short time horizons - where conventional business horizons prevent long term investment (ex.: energy efficiency),

- fragmented institutions - where complex problems cannot be solved, because the self-interest outweighs the common interest of the organizations involved (ex.: urban regeneration).

This list could go on. The point here is the way in which each of these barriers is a kind of ,system condition" of modern liberal democracy (4). The implication is that such system-level barriers might be overcome by facilitating changes to the system itself. This may be more beneficial and effective by making new links, new communications paths, and increasing the diversity, self-organizing capacity and self-awareness of the system as a whole.

\section{... and Toolkits}

The question is, what kind of toolkit can be a catalyst to enable the system to change itself? We can put up a working hypothesis: where there is a barrier, there is generally a toolkit to enable an evolutionary change to the system which produces that barrier. Following the barrier examples above:

- Critical mass: information on potential but diffused market demand can be collected and coordinated, so that economies of scale then become possible. This is an obvious application for internet technology, as for example with the new low-
Kommunikation eines Leitbildes

Nachhaltigkeit - was ist das? Unter Kommunikationsstrategien und nachhaltigen Ideen können sich die meisten Menschen wenig bis gar nichts vorstellen. Ist Nachhaltigkeit nur eine Hülle ohne Inhalt oder ein Thema, über das schon alles gesagt worden ist? Wie lässt sich ein solches Leitbild kommunizieren, ohne die Empfänger aus den Augen zu verlieren? Wer sind überhaupt die Adressaten? PolitikerInnen, ManagerInnen oder die Bürgerlnnen?

Die Ausgabe 63/64 der politischen ökologie versucht, das Rätsel Nachhaltigkeit zu knacken sowie neue und alternative Kommunikationswege aufzuzeigen.

Plus Literatur special 2000 -

Die Umweltbücher des Jahres.

\section{www.oekom.de}

Für 10,00 Euro erhältlich bei pan adress

Semmelweisstraße 8, D-82152 Planegg

Fon $++49 /(0) 89 / 857$ 09-145

Fax ++49/(0)89/857 09-131

E-Mail kontakt@oekom.de 
cost airlines. In the case of renewable energies, the UK market in green electricity is now growing rapidly with the aid of internet purchasing.

- Split responsibility: information toolkits which provide feedback to producers and consumers help to overcome this problem. In the case of public transport, there is a new generation of green travel plans around the EU: many of these are learning to use information systems to coordinate demand and supply, to feedback the results of individual choices, and to target investment closely to travel demand and supply.

- Short time horizons: Standard investment horizons can be increased by re-structuring financial risk and security arrangements. Increasing the range and quality of market information for investment decisions tends to build up shared equity and stakeholding. In the case of energy efficiency, there are experiments on providing feedback to consumers, and building/energy data to producers and landlords, which help to increase the effective payback period and investment horizon.

- Fragmented institutions: Where toolkits can provide information and feedback on the effects of individual actions, complex problems are more likely to be shared by different organizations. For urban regeneration, this is a real challenge - the information systems which can provide solutions, can also produce the social exclusion which is part of the problem. Again, information systems in planning and evaluation are providing a new paradigm for decision-making in urban regeneration. We now have object-oriented systems focused on people, on places, on activities, and on programmes: but integration between each of these has not yet been realized.

\section{Integration of Toolkits}

We are clearly a long way from such an ideal, but some initiatives are aiming in that direction: one example is the Sustainable City-Region programme at the Centre for Urban \& Regional Ecology. This follows the theme of convergence of toolkits, through a series of projects aimed at different parts of the policy and business cycle:

- Visioning and elicitation (finding out what people want),

- strategic planning and investment,

- management and implementation,

- evaluation, monitoring and reporting.

Each of these tollkits is tending to use common datasets, common methods and common information systems for every aspect of policy and practice, as shown by the practical projects (5):

- Geographical information systems (GIS) the North West (NW) Explorer, a pioneering visualization package for 63 spatial datasets.

- Future information systems (FIS) - the NW Quest, a regional urban development model, and the NW Futures scenario building project.

- Resource information systems (RIS): the NW Resource Flow Audit and Eco-Region projects, centred on the environmental metabolism.

- Management information systems (MIS): the Integrated Sustainable Cities Assessment Method (ISCAM) and the NW Action for Sustainability and Integrated Appraisal projects.

Each of these toolkits is an early step on a long road. In general, they highlight a fundamental tension between two opposing approaches:

- The SD agenda of vertical, horizontal and lateral connectivity between sectors, stakeholders, timescales, causes and effects - where almost everything is linked to almost everything else, in an integrative approach.

- The policy agenda of rational management - where specific and accountable links are needed between inputs, outputs and outcomes, in a reductive value for money type of approach.

I would suggest this tension is likely to dominate the future development of toolkits for regional SD

\section{literatur zum Schwerpunkt}

AG Land- und Regionalentwicklung an der GH Kasse (Hrsg.): Netzwerke in der Regionalentwicklung (Arbeitsergebnisse H. 52). Kassel 2001.

Brendle, Uwe: Musterlösungen im Naturschutz Politische Bausteine für erfolgreiches Handeln (= Hrsg. Bundesamt für Naturschutz - BfN). Bonn 1999.

Bundesamt für Bauwesen und Raumordnung (Hrsg.): Gute Beispiele einer nachhaltigen regionalen Raum- und Siedlungsentwicklung. Werkstatt: Praxis Nr. 1/2000. Bonn.

Cooke, P., Boekholt, P. and Tödtling, F.: The governance of innovation in Europe: regional perspectives on global competitiveness. London, New York 2000.

ENSURE (European Network on Sustainable Urban and Regional Development) (Hrsg. SUSTAIN): Making sustainable regional development visible - Evaluation methods and indicators in the regional context. Graz 2000.

ENSURE (Hrsg. SUSTAIN): Higher education for sustainable regional development. Graz 2000.

European Commission: Sustainable governance. Institutional and procedural aspects of sustainability. Luxembourg 2000.

Knieling, J.: Leitbildprozesse und Regionalma-
- the more sophisticated the technical information systems become, the more we will find questions which cannot be answered by technical means alone. Meanwhile the opportunities for new toolkits in promoting regional SD are clear.

\section{References}

(1) Gabriel, I./ Narodoslawsky, M. (eds.): Regions - Cornerstones for Sustainable Development. Proceedings of the Symposium, SUSTAIN, Graz 1998.

(2) Mulgan, G.: Connexity, London 1997 (Calder/Boyars).

(3) Ravetz, J.: City-Region 2020: integrated planning for a sustainable environment. London 2000 (Earthscan).

(4) Bossel, H.: 20/20 Vision: Explorations of Sustainable Futures. Centre for Environmental Systems Research, University of Kassel 1996.

(5) For detailed information, see www.art.man.ac.uk/ PLANNING/cure/research_frames.html

\section{Der Autor}

Joe Ravetz is the Director of the Sustainable City-Region programme at the Centre for Urban \& Regional Ecology (CURE), University of Manchester.

Kontakt: CURE, School of Planning \& Landscape, Manchester University, Oxford Rd, Manchester MI3 9PL, UK. Tel. 0044-161275-6879/ 6938, Fax -6893, E-mail: joe.ravetz@man.ac.uk 
(c) 20I0 Authors; licensee IÖW and oekom verlag. This is an article distributed under the terms of the Creative Commons Attribution Non-Commercial No Derivates License (http://creativecommons.org/licenses/by-nc-nd/3.o/), which permits unrestricted use, distribution, and reproduction in any medium, provided the original work is properly cited. 